\title{
Comparative treatment of induced ulcerative colitis in male rat model by using cinnarizine and sulfasalazine
}

\author{
R.K. Attarbashee ${ }^{1}$ and A. Abu-Raghif ${ }^{2}$ \\ ${ }^{1}$ Department of Dental Basic Science, College of Dentistry, University of Mosul, Mosul, ${ }^{2}$ Department of Pharmacology and \\ Therapeutics, College of Medicine, Al- Nahrain University, Baghdad, Iraq \\ Emails: ${ }^{1}$ ranaatarbashe@gmail.com, ${ }^{2}$ ar-armat1967@yahoo.com
}

(Received October 15, 2019; Accepted December 4, 2019; Available online September 2, 2020)

\begin{abstract}
Ulcerative colitis is a chronic and intermittent illness. The current treatment failed to cure the disease which requires to investigate other drug with minimal side effects. The goal of the research is to assess the histological outcome, antioxidant and anti-inflammatory effects of cinnarizine in comparison with that of sulfasalazine (salazosulfapyridine) in experimentally induced colitis in rats. Acetic acid $4 \%$ (vol/ $/ \mathrm{vol})$ was used rectally to induce experimental colitis in rats. After induction, rats were administered either sulfasalazine $100 \mathrm{mg} / \mathrm{kg}$ or cinnarizine $20 \mathrm{mg} / \mathrm{kg}$ as a therapeutic dose in rats orally for one week. The duration of treatment was depended on previous studies. There were estimation of histopathological and clinical parameters also the expression of cytokines (tumor necrosis factor alpha (TNF- $\alpha$ ) and interleukin-4 (IL-4)), oxidative stress markers (malondialdehyde (MDA) and myeloperoxidase (MPO)), and adhesion molecules (intercellular adhesion molecule-1 (ICAM1) and endothelial (E)-Selectin) in the colonic tissue. Results showed that both cinnarizine and sulfasalazine significantly reduced the clinical and histological injury in colon that induced by acetic acid. In addition to the down regulation of the increased colonic cytokines, MDA, MPO parameters and adhesive molecules. These results concluded that cinnarizine had an effective therapeutic role which is comparable with sulfasalazine on the experimental colitis through anti-inflammatory and antioxidant actions with down regulation the colonic adhesion molecule.
\end{abstract}

Keyword: Cinnarizine, Ulcerative colitis, Acetic acid, Oxidative stress, Adhesion molecules

DOI: 10.33899/ijvs.2019.126170.1254, (O2020, College of Veterinary Medicine, University of Mosul.

This is an open access article under the CC BY 4.0 license (http://creativecommons.org/licenses/by/4.0/).

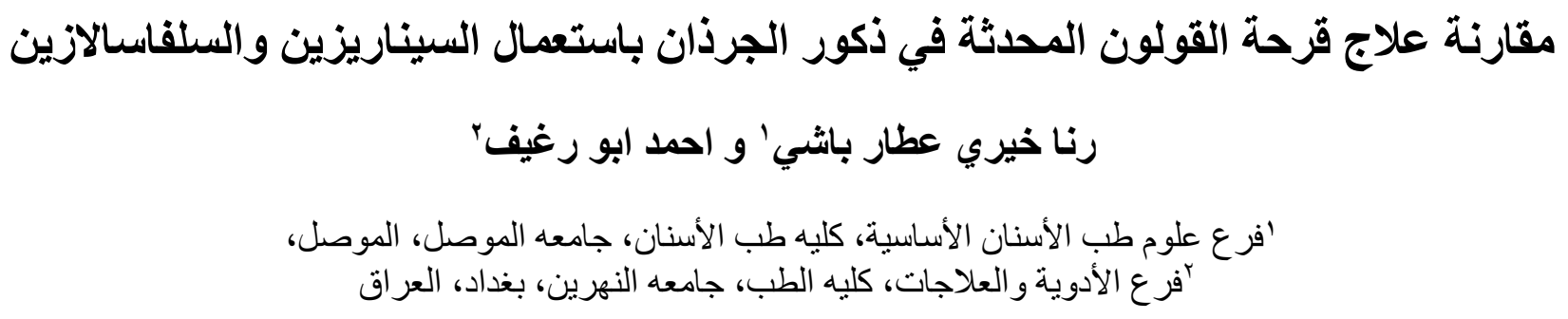

ان مرض التهاب القولون التقرحي ذو طبيعة مزمنة ومتقطعة. وان فثل العلاج بعد فترة وجيزة كان دافعا كبير الفحص تأثثر ات اتل علاج

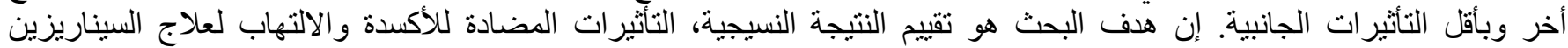
بالمقارنة مع علاج السلفاسالازين في قرحة القولون المحدثة في الجرذان. تم استعمال حامض الخليك المخفف بتركيز ؛ ؛

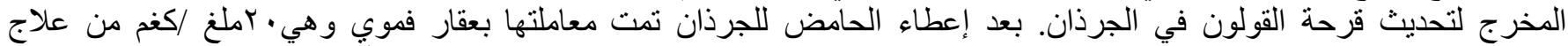

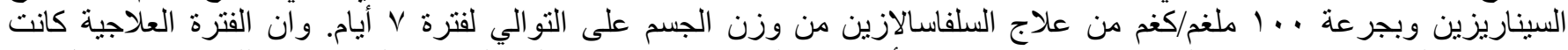

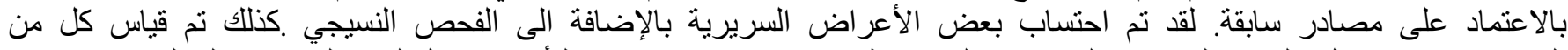
السايتوكينات (معامل الورم التنخري الفا والانترلوكين الرابع)، معايير الإجهاد التأكسدي (المالوندايالديهايد والمايلوبيروكسيديز) 


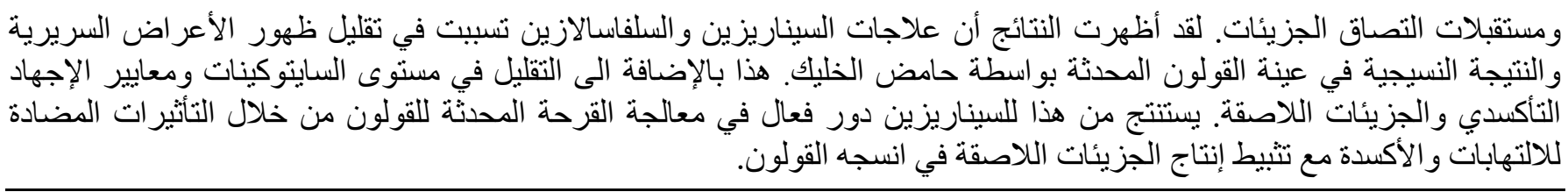

\section{Introduction}

Ulcerative colitis is one of the chronic, recurrent and inflammatory intestinal illness. Although its etiology is unknown, but several studies indicated that altered immunity, genetic and environmental factors are intercepted with the pathogenesis of colitis. In the past years despite the high awareness for that disease, the utilization of remedies is still insufficient $(1,2)$. The induction of colitis by acetic acid is widely used as experimental pattern (3). It is effective for the investigation the pathogenesis of ulcerative colitis and novel options for treatment (4). Aminosalicylates, immunomodulators, glucocorticoids, and monoclonal antibodies are pharmacological treatment for ulcerative colitis. Regardless, the increased proportion of undesirable effects at the same time with insufficient therapy get by necessary to inspect novel drug with high effectiveness (5).

Cinnarizine is a drug, it belongs to piperazine derivative. The proposed therapeutic mechanism is through blocking effect of histamine (H1) and calcium channel receptors $(6,7)$. Histamine (8) and calcium influx (9) have great effect concerning the inflammatory role in gastrointestinal tract. Also cinnarizine has antiserotonergic effect (10) and serotonin play an integral role in pathogenesis of ulcerative colitis (11). Cinnarizine was suggested to inhibit the inflammatory response through the oedema reduction caused by indomethacin in rats (12). The current study assesses the protective effect of cinnarizine, a potent antagonist activity on histamine $\mathrm{H} 1$ and calcium channel receptors, versus sulfasalazine in case of experimentally induced ulcerative colitis.

\section{Materials and methods}

Forty-eight Wister albino adult male rats 200-220 g were used throughout this study (supplied from animal house of the national center for drug control and researches). Prior to the experiment, animal was placed five per cage that was supplied with a large wire -mesh floor for 7 days and were allowed to administer water and laboratory chow pellet. Study protocol were approved by institutional animal ethics committee from the Al-Nahrain university in the college of medicine.

\section{Chemicals and drugs}

Acetic acid and diethyl ether (BDH Chemical Ltd., England), immunohistochemistry kits (Abcam/UK), sulfasalazine $2 \mathrm{ml} / \mathrm{kg}$ orally, and cinnarizine $4 \mathrm{ml} / \mathrm{kg}$ orally (Sigma-Aldrich) were purchased.

\section{Experimental design}

Rats were classified to four groups $(n=12$ in each group). The Group I received no treatment and served as normal control while the other groups, colitis (group II) was induced by rectal administration of $4 \%$ acetic acid (v/v). The group II was administered orally normal saline; while group III was administered cinnarizine $20 \mathrm{mg} / \mathrm{kg}(4 \mathrm{ml} / \mathrm{kg})$ orally and lastly group IV treated orally with sulfasalazine (Salazosulfapyridine) $100 \mathrm{mg} / \mathrm{kg}(2 \mathrm{ml} / \mathrm{kg})$, sixty minutes after the induction of colitis for 7 days. The duration of treatment was depended on previous studies of experimental colitis $(13,14)$.

\section{Induction of ulcerative colitis}

Before the colitis induction, rats were fasted for at least $24 \mathrm{hrs}$ to get proper induction of colitis by evacuation the colon from feces but where be permitted to tap water. Experimental colonic ulceration was accomplished after interruption of water ( 2 hours) in accordance to that procedure suggested by Mousavizadeh et al. (15) with modification. Briefly, rats were received single intrarectal infusion of $4 \%$ acetic acid in a dose $5 \mathrm{ml} / \mathrm{kg}$ solution for $30 \mathrm{~s}$ ( $8 \mathrm{~cm}$ into the colon) under light ether anesthesia by flexible plastic tube ( $2 \mathrm{~mm}$ extrinsic diameter). Rats were positioned in horizontal direction for $2 \mathrm{~min}$ to prevent the discharge of acetic acid. Rats in group 1 go through the identical procedure by using the same amount of normal saline as an alternative to acetic acid.

\section{Preparation of drugs}

The sulfasalazine and cinnarizine were freshly prepared before administration. Estimated drugs were prepared as suspensions in the distilled water. Cinnarizine was used at a dose $20 \mathrm{mg} / \mathrm{kg}$ as a therapeutic dose in rats according to the study reporting that the highest inhibitory effect of cinnarizine on edema formation and inflammatory modulation (12). Sulfasalazine $100 \mathrm{mg} / \mathrm{kg}$ was served as standard therapy $(16,17)$.

\section{Assessment of colitis}

At the end of the experimental period, rats inhaled an excessive dose of diethyl ether in order to sacrifice them. The colon was removed rapidly after dissection of the abdomen. The specimen of colon was opened longitudinally and gently cleaned with normal saline. Then, 
the assessment of clinical features were achieved by normal observation. Finally, the samples were assessed for histopathologic and immunohistochemical changes.

\section{Disease Activity Index (DAI)}

The Disease activity index defined by Niu et al. (18) was used to assess the disease clinically which involve body weight reduction $(0=$ weight gain or no reduction, $1=1-5 \%$ reduction, $2=6-10 \%$ reduction, $3=11-15 \%$ reduction, $4=$ more than $15 \%$ reduction); the consistence of faeces $(0=$ normal, $2=$ loose faeces, $4=$ diarrhea $)$ and bleeding of rectum $(0=$ normal, $2=$ mild bleeding, $4=$ severe bleeding). The calculation was made by combination of the total scores of DAI.

\section{Colon edema}

It was utilized as an indicator of edematous tissue and the intensity of colitis. After the incision was done along the mesenteric margin of each colonic specimen and washed gently, the colon edema was determined by measuring the colon weight by using sensitive balance (19).

\section{Macroscopic colonic score}

The colonic samples were examined visually. The macroscopic score based on the clinical features of the colon according to scoring system ranging from $0-6$ as follows: $0=$ absence of inflammation; $1=$ redness or swelling; $2=$ swelling and redness; $3=$ one or two ulcers; $4=$ one large ulcer or more than two ulcers; $5=$ initial necrosis; 6 , severe necrosis $(20)$.

\section{Histopathological evaluations}

Formalin $10 \%$ was used to fix the colonic samples. Dehydration, paraffin embodiment and deparaffinization were done on the samples. Colonic samples were cut into sections $(4 \mu \mathrm{m})$ and dyed with Hematoxylin and eosin (H\&E).

The histopathological changes were assessed by examining and scoring the slides. Experienced histopathologist tested the tissue sections in a blinded manner and results evaluated according to scoring system ranging from $0-3(0=$ normal; $1=$ focal; $2=$ =zonal; $3=$ sever $)$ which assessed the extent of: destruction of glands and epithelium, glandular crypts dilation, depletion of goblet cells, infiltration of inflammatory cells, edema, dysplasia, mucosal hemorrhage and crypt abscesses (21).

\section{Immunohistochemistry}

Immunohistochemistry (IHC) directly demonstrated the cells in the affected tissue (22). The immunohistochemical reactions were produced by presence of specific antibodies, simultaneously the evaluation of the production a number of biochemical markers in intestinal samples that were paraffin- embedded in order to measure the colonic cytokines (tumor necrosis factor-alpha and interleukin-4), adhesion molecules (intercellular adhesion molecules-1 (ICAM-1) and endothelial selectin (E-selectin) and oxidative stress parameters (Malondialdehyde (MDA), Myeloperoxidase (MPO)).

Quantification of IHC was performed in accordance to the following semiquantitative scores (23), which was based on the percentage of positively stained cells as following :0, no staining; $1, \leq 25 \% ; 2,26-50 \% ; 3,51-75$ $\%$; and $4,76-100 \%$.

\section{Statistical Analysis}

Statistical package for social science version 23 software program was used to summarize, analyze and present the data. Quantitative (numeric) variables were expressed as mean and standard deviation.

One-way ANOVA was used to study difference in mean of quantitative variables among groups; then followed by post hoc least significant difference (LSD) test to evaluate mean difference within groups. The significant level was considered at $\mathrm{P} \leq 0.05$ (24).

\section{Results}

\section{The influence of cinnarizine on clinical parameters}

The colonic mucosa was extensively ulcerated and showed necrotic tissue in colitis group in contrast to control normal group. Even so, after the induction of colitis, the rats that received cinnarizine or sulfasalazine elicit orally significant reduction to the disease activity index and colon weight. Additionally, two drugs significantly reduce the macroscopical score. However, cinnarizine produced a higher significant reduction in the macroscopical score in comparison to the sulfasalazine group as displayed in table 1 .

\section{The influence of cinnarizine on histopathological score}

The current study exhibits the histological changes in colitis group, primarily loss of architecture in the intestinal crypt, extensive mucosal colonic damage, ulcerations and necrosis compared to normal control group.

Furthermore, both sulfasalazine and cinnarizine administered groups elicit significant reduction in the microscopical score as specified by colonic mucosa epithelization, reduction of neutrophil infiltration and edema compared to acetic acid induced colitis group. Even so, cinnarizine exhibited higher significant reduction in the scoring of microscopical parameter compared to sulfasalazine that displayed in table 2 and figures 1,2, 3 .

\section{The influence of cinnarizine on cytokines (IL-4 and TNF- $\alpha$ ) \\ Oral treatment of cinnarizine or sulfasalazine to the} colitis group was significant. It was diminished by IL-4 and 
TNF- $\alpha$ in comparison with colitis. However, cinnarizine exhibited better significant reduction in the IL- 4 and TNF- $\alpha$ level compared with sulfasalazine group as displayed in table 2 and figures 4,5 .

\section{The influence of cinnarizine on oxidative stress markers (MDA and MPO)}

After sulfasalazine and cinnarizine treatment, the high colonic MDA level in the induced group was found to be significantly diminished. Even so, cinnarizine elicit a better significant reduction in the level of MDA in comparison to sulfasalazine group. Also, both drugs produce significant declination in MPO in comparison with induced group as displayed in table 3 and figures 6,7 .

\section{The influence of cinnarizine on adhesion molecules (ICAM-1 and E-selectin)}

As displayed in table 3 and figures 8,9. There are elevated level of ICAM-1 and E-selectin after the induction by acetic acid in comparison with that of normal group. While these findings elicit significant declination in the cinnarizine and sulfasalazine treatment. However, cinnarizine produced a better significantly declination in the adhesive molecules (ICAM-1) in comparison to sulfasalazine administered group.

Table 1: Macroscopic parameters in study and healthy control groups

\begin{tabular}{lcccc}
\hline \multirow{2}{*}{ Clinical parameters } & \multicolumn{4}{c}{ Groups (n=12/group) mean \pm Standard Deviation (SD) } \\
\cline { 2 - 5 } & Control & Colitis group & Sulfasalazine treated group & Cinnarizine treaterd group \\
\hline Disease activity index & $0.0 \pm 0.0 \mathrm{a}$ & $11.17 \pm 1.27 \mathrm{~b}$ & $2.33 \pm 1.56 \mathrm{c}$ & $1.67 \pm 0.78 \mathrm{c}$ \\
Colonic weight (gram) & $1.5 \pm 0.22 \mathrm{a}$ & $3.54 \pm 0.4 \mathrm{~b}$ & $1.67 \pm 0.39 \mathrm{c}$ & $1.58 \pm 0.35 \mathrm{c}$ \\
Macroscopic score & $0.0 \pm 0.0 \mathrm{a}$ & $5.75 \pm 0.36 \mathrm{~b}$ & $2.0 \pm 0.6 \mathrm{c}$ & $1.5 \pm 0.52 \mathrm{~d}$ \\
\hline
\end{tabular}

Comparison expressed by letters; dissimilar letters denotes significant difference.

Table 2: Cytokines immunohistochemical score and histopathological parameters

\begin{tabular}{lcccc}
\hline \multirow{2}{*}{ Cytokines parameters } & \multicolumn{3}{c}{ Groups (n=12/group) mean \pm Standard deviation (SD) } \\
\cline { 2 - 5 } & Control & Colitis & Sulfasalazine treated group & Cinnarizine treaterd group \\
\hline Histopathology & $0.0 \pm 0.0 \mathrm{a}$ & $3.0 \pm 0.0 \mathrm{~b}$ & $1.67 \pm 0.49 \mathrm{c}$ & $0.67 \pm 0.49 \mathrm{~d}$ \\
Interleukin-4 & $1.0 \pm 0.0 \mathrm{a}$ & $4.0 \pm 0.0 \mathrm{~b}$ & $2.0 \pm 0.0 \mathrm{c}$ & $1.33 \pm 0.49 \mathrm{a}$ \\
Tumor necrosis factor $-\alpha$ & $1.0 \pm 0.0 \mathrm{a}$ & $4.0 \pm 0.0 \mathrm{~b}$ & $2.67 \pm 0.49 \mathrm{c}$ & $1.33 \pm 0.49 \mathrm{a}$ \\
\hline
\end{tabular}

Comparison expressed by letters; dissimilar letters denotes significant difference.

Table 3: Immunohistochemical score for oxidative stress and adhesive molecules

\begin{tabular}{lcccc}
\hline Oxidative stress and & \multicolumn{4}{c}{ Groups (n=12/group) mean \pm Standard Deviation (SD) } \\
\cline { 2 - 5 } Adhesive molecules & Control & Colitis & Sulfasalazine treated group & Cinnarizine treaterd group \\
\hline Myeloperoxidase & $1.00 \pm 0.0 \mathrm{a}$ & $4.0 \pm 0.00 \mathrm{~b}$ & $1.83 \pm 0.38 \mathrm{c}$ & $1.67 \pm 0.49 \mathrm{c}$ \\
Malondialdehyde & $1.0 \pm 0.0 \mathrm{a}$ & $4.0 \pm 0.0 \mathrm{~b}$ & $2.58 \pm 0.51 \mathrm{c}$ & $1.25 \pm 0.452 \mathrm{a}$ \\
ICAM-1 & $1.0 \pm 0.0 \mathrm{a}$ & $4.0 \pm 0.0 \mathrm{~b}$ & $2.5 \pm 0.522 \mathrm{c}$ & $1.5 \pm 0.52 \mathrm{~d}$ \\
E-selectin & $1.0 \pm 0.0 \mathrm{a}$ & $4.0 \pm 0.0 \mathrm{~b}$ & $1.92 \pm 0.51 \mathrm{c}$ & $1.75 \pm 0.4 \mathrm{c}$ \\
\hline
\end{tabular}

Comparison expressed by letters; dissimilar letters denotes significant difference.

\section{Discussion}

This study demonstrated the effect of cinnarizine on experimentally colitis. It is concluded that cinnarizine significantly reduced the mean DAI. The weight of the inflamed colonic tissue is considered as a reliable and sensitive indicator for the severity and extent of intestinal inflammation (25). However, the current study showed that cinnarizine has decreased the weight of colonic tissue in colitis group which was comparable to the suggestion of Abdel Salam (12) who showed that cinnarizine produced an inhibitory effect on edema formation and gastric mucosal lesion caused by indomethacin in rats. Moreover, cinnarizine in the present study reduced macroscopic and the scoring of histopathological changes in colitis. The proposed protective mechanism of cinnarizine is through blocking effect of histamine and calcium channel receptors $(6,7)$. The increased histamine has an important role in the inflammation of the gastrointestinal tract (8). It showed that calcium is responsible for the stimulation of nuclear factor $\left(\mathrm{NF}_{\mathrm{k}} \mathrm{B}\right)$ activity (7). 


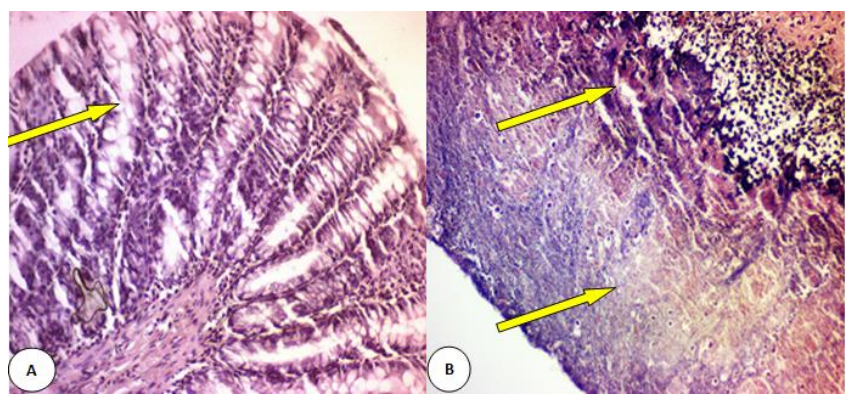

Figure 1: Histological section throughout the wall of colon reveals $\mathrm{A}$, the normal mucosa and submucosa without any inflammatory signal and conservation of goblet cells in colon; B, extensive ulceration; necrosis with no gland; and mononuclear inflammatory infiltrate (yellow arrow) in experimentally colitis in rat, hematoxylin and eosin stain; $40 \mathrm{X}$.

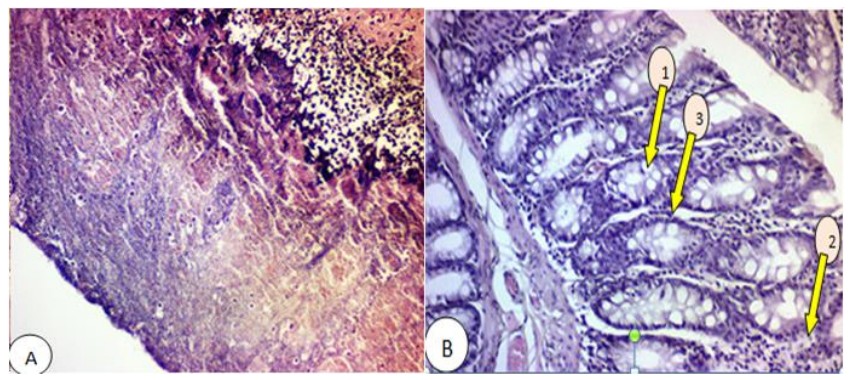

Figure 2: Histological section throughout the colonic wall reveals A, extensive ulceration; necrosis with no gland; B, the effects of cinnarizine after 7 days and exhibit (1) the regeneration of mucosa and formation of glands; (2) least severe inflammation and (3) regeneration of goblet cells; B, hematoxylin and eosin stain; $40 \mathrm{X}$.

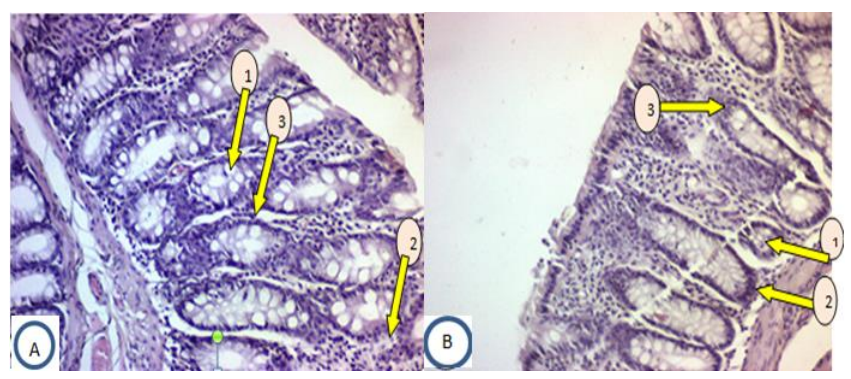

Figure 3: Histological section throughout the colonic wall reveals the effects of $\mathrm{A}$, cinnarizine ; $\mathrm{B}$, sulfasalazine after 7 days and exhibit (1) the regeneration of mucosa and formation of glands; (2) least severe inflammation and (3) regeneration of goblet cells; hematoxylin and eosin stain; $40 \mathrm{X}$.

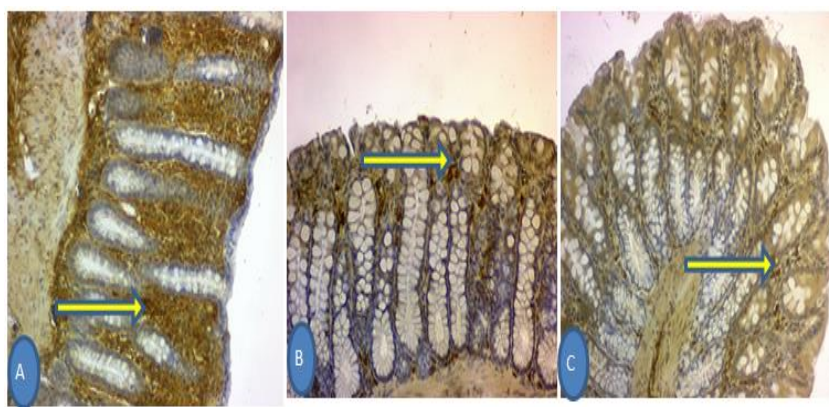

Figure 4: Immunohistochemical expression of interleukin-4 reveals secretory pattern (brown color in the stromal cells). A, score-4; B, cinnarizine treated group (score-1); C, sulfasalazine treated group (score-2); hematoxylin, 20X.

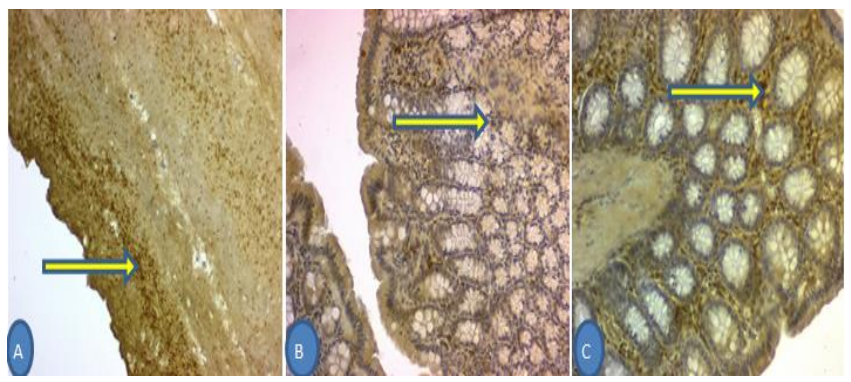

Figure 5: Immunohistochemical expression of tumor necrosis factor- $\alpha$ (TNF- $\alpha$ ) reveals membranous and secretory pattern (brown color in the stromal cells); A, colitis group (score-4); B, cinnarizine treated group (score1); C, sulfasalazine treated group (score-2); hematoxylin; 20X.

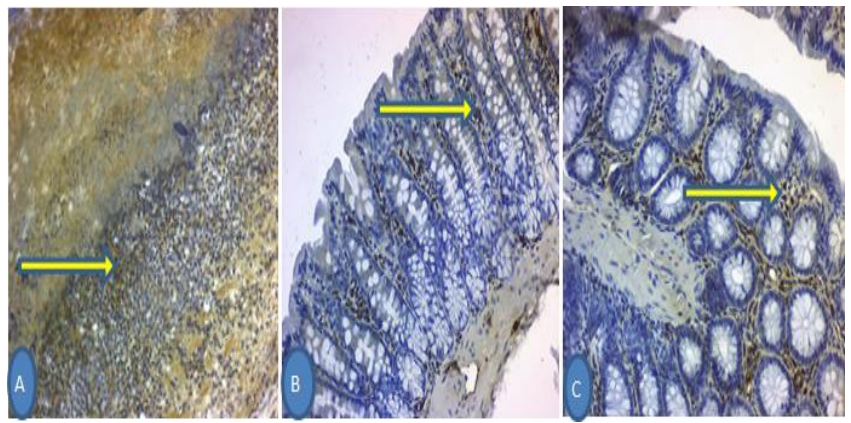

Figure 6: Immunohistochemical expression of myeloperoxidase (MPO) reveals cytoplasmic pattern (brown color in the stromal cells); A, colitis group (score4); B, cinnarizine treated group (score-1); C, sulfasalazine treated group (score-2); hematoxylin; 20X. 


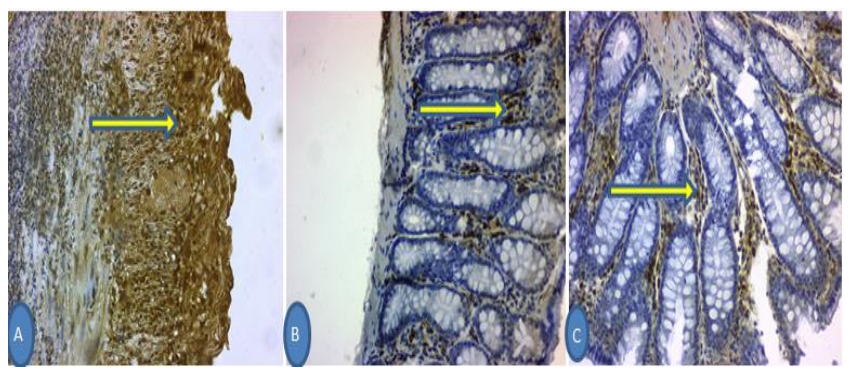

Figure 7: Immunohistochemical expression of malondialdehyde (MDA) reveals cytoplasmic pattern (brown color in the stromal cells); A, colitis group (score4); B, cinnarizine treated group (score-1); C, sulfasalazine treated group (score-2); hematoxylin; 20X.

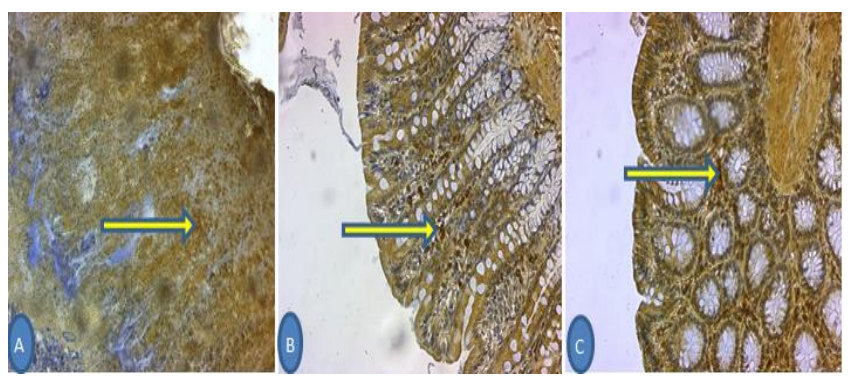

Figure 8: Expression of ICAM-1 by Immunohistochemistry reveals membranous pattern (brown color in the stromal cells); A, colitis group (score-4); B, cinnarizine treated group (score-1); C, sulfasalazine treated group (score-2); hematoxylin; 20X.

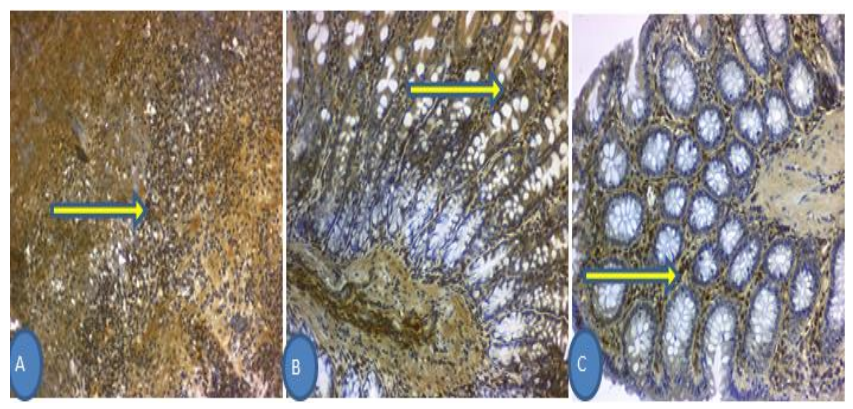

Figure 9: Immunohistochemical expression of E-selectin reveals membranous pattern (brown color in the stromal cells); A, colitis group (score-4); B, cinnarizine treated group (score-1); C, sulfasalazine treated group (score-2); hematoxylin; 20X.

The effect of calcium ions on Ieukotriene synthesis with the enzyme 5-lipooxygenase from arachidonic acid has been suggested and the enzyme 5-lipooxygenase is calcium dependent and requires adenosine triphosphate (26). Also cinnarizine has antiserotonogeric effects (10).
Serotonin (5-Hydroxytryptamine) receptors are highly expressed in intestinal tissues and play an integral role in pathogenesis of ulcerative colitis (11).

There was a close relation between ulcerative colitis and inflammation (27). Tumor necrosis factor- $\alpha$ is a crucial proinflammatory cytokine liberated from the lymphocytes and macrophages in the initial step of inflammation, also, it has been noted that TNF- $\alpha$ has great participation in the pathogenesis of colonic ulceration $(28,29)$. Interleukin -4 is a key immunoregulatory cytokine (T-helper-2) and it contribute in down regulation the release of pro inflammatory cytokines (30). The dysregulation of IL-4 may assist in inflammation and pathogenesis of intestinal ulceration by reducing resistance in intestinal epithelial cells (31), goblet cell hyperplasia (32) and exotoxin expression in colonic mucosa (33). Kasaian et al. showed the involvement of IL-4 in experimental colitis that induced by oxazolone, a model of ulcerative colitis in mice (34). The present study explained the administration of cinnarizine causes significant reduction in the expression of immunohistochemistry for colonic cytokines (interleukin-4 and tumor necrosis factor- $\alpha$ ) in experimentally induced colitis in rats. Previous study showed that Cinnarizine has anti-inflammatory through it's suppressant effect on pro inflammatory cytokines TNF- $\alpha$, IL-1, and IL-6 release in experimentally-induced bronchial asthma in rats (35).

Malondialdehyde produced from the peroxidation process of lipid $(36,37)$ which causing destruction of colonic tissue in ulcerative colitis (38) and cell necrosis (39). Myloperoxidase is a hemoprotein enzyme abdudantly released from the neutrophils granules by inflammatory stimuli that catalyzes the formation of a number of reactive species (40). Studies have indicated that oxidative stress results from the shift of equilibrium between the prooxidant and anti-oxidant systems in favor of the pro-oxidant system which result of excessive production of free oxygen radicals and neutrophil infiltration $(41,42)$. The study has also shown that administration of cinnarizine significantly reduce the expression of immunohistochemistry for markers of oxidative stress (myeloperoxidase and malondialdehyde) in colonic mucosa of experimentally induced colitis in rats. Studies have suggested that cinnarizine reduces the immune response through inhibition of endothelial oxidative stress and nuclear factor (NF- $\kappa B$ ) action (the transcription factor through signaling pathways of phospholipase $\mathrm{C}$ and the phosphatidylinositol) (35).

Inter Cellular adhesive molecule (ICAM-1) engage the leukocytes association to endothelial cells, that simplify their penetration to the inflammatory site. Endothelial selectin is particularly interesting because it is only found in the activated endothelium, in contrast with other adhesion molecules, which have a more widespread tissue distribution. The demonstration of E-selectin can thus be considered conclusive evidence of endothelial activation 
(43). Endothelial selectin is biologically active, facilitating the early phase of polymorphonuclear adhesion to the endothelial cell, constituting an early marker of the inflammatory response (44). The present study showed that cinnarizine significantly reduced immune histochemical expression of adhesive molecules in rat colonic mucosa in contrast to colitis group and this evidence is corresponding with Haress (45). that showed cinnarizine can inhibit the cell adhesion molecules, and chemotactic factors.

\section{Conclusions}

Cinnarizine has a therapeutic effect through the antioxidant and anti-inflammatory effects which is comparable to that of sulfasalazine in experimentally induced colitis.

\section{Acknowledgements}

I would like to express my thanks for pathologist Dr. Ban Jumaa Qasim /College of medicine /Al-Nahrain University for support in evaluation of research. Also, I am very grateful to the University of Mosul/College of Dentistry for their provided facilities, which helped to improve the quality of this work.

\section{Conflict of interest}

There is no conflicts of interest.

\section{References}

1. Nagib MM, Tadros MG, Elsayed MI, Khalifa AE. Anti-inflammatory and antioxidant activities of Olmesartan midoxomil ameliorates experimental colitis in Rats. Toxicol Appl Pharmacol. 2013;271:106113. Doi: http://dx.doi.org/10.1016/j.taap.2013.04.026

2. Sotnikova R, Nosalova V, Navarova J. Efficacy of quercetin derivatives in prevention of ulcerative colitis in rats. Interdiscip Toxicol. 2013;6:9-12. Doi: http://dx.doi.org/10.2478/intox-2013-0002

3. Akkol EK, Dereli FT, Taştan H, Sobarzo-Sánchez E, Khan H. Effect of Sorbus domestica and its active constituents in an experimental model of colitis rats induced by acetic acid. J Ethnopharmacol. 2019;251:112521. DOI: 10.1016/j.jep.2019.112521

4. Vishwakarma N, Ganeshpurkar A, Pandey V, Dubey N, Bansal D. Mesalazine-probiotics beads for acetic acid experimental colitis: Formulation and characterization of a promising new therapeutic strategy for ulcerative colitis. Drug Deliv. 2015;22:94-99. Doi: 10.3109/10717544.2013.872711

5. Baumaqart DC, Sandbom WJ. Inflammatory bowel disease: Clinical aspects and established and evolving therapies. Lancet. 2007;369:1641-1657. Doi: dx.doi.org/10.1016/S0140-6736(07)60751$\mathrm{X}$

6. Pinto EG, da Costa-Silva TA, Tempone AG. Histamine H1-receptor antagonists against Leishmania (L.) infantum: An in vitro and in vivo evaluation using phosphatidylserine-liposomes. Acta Trop. 2014;137:206-210. Doi: 10.1016/j.actatropica.2014.05.017.

7. Ashrafi MR, Salehi S, Malamiri RA, Heidari M, Hosseini SA, Samiei M, Tavasoli AR, Togha M: Efficacy and safety of cinnarizine in the prophylaxis of migraine in children: a double-blind placebo-controlled randomized trial. Pediatr Neurol. 2014;51:503-508. doi: 10.1016/j.pediatrneurol.2014.05.031.

8. Mantz L, Novak N. Histamine and histamine intolerance. Am J Clin Nutr. 2007;85(5):1185-1196. Doi: doi.org/10.1093/ajen/85.5.1185

9. Kav A, Akyol E, Aksoy C, Ozer M, Torgutalp B. Azelnidipine, a novel calcium channel blocker, ameliorates severity of colitis in DSS induced colitis in mice possibly by modulating tissue levels of TNFalpha and IL-6. JCC. 2017;11(1):S93-S94. Doi: 10.1093/eccojcc/jjx002.155

10. Fabiani G, Pastro PC, Froehner C. Parkinsonism and other movement disorders in outpatients in chronic use of cinnarizine and flunarizine. Arq Neuropsiquiatr. 2004;62(3B):784-788. Doi:10.1590/s0004$282 \times 2004000500008$.

11. Regmi SC, Park SY, Ku SK, Kim JA. Serotonin regulates innate immune responses of colon epithelial cells through Nox2-derived reactive oxygen species, Free Radical Biol Med. 2014; 69:377-389. doi: 10.1016/j.freeradbiomed.2014.02.003.

12. Abdel-Salam OM. Modulation of visceral nociception, inflammation and gastric mucosal injury by cinnarizine. Drug target Insights. 2007;2:29-38.

13. Rashidian A, Muhammadnejad A, Dehpour A, Mehr SE. Atorvastatin attenuates TNBS-induced rat colitis: the involvement of the TLR4/NF-KB signaling pathway. Inflamm Pharmacol. 2016;24(23):109-118. Doi: https://link.springer.com/aticle/10.1007/s10787-0160263-6

14. Manna MJ, Abu-Raghif A, Abood MS. Effect of captopril on inflammatory biomarkers, oxidative stress parameters and histological outcome in experimental induced colitis. J Pharm Sci Res. 2007;9(9):1629-1636.

15. Mousavizadeh K, Rahimian R, Fakhfouri. Anti-inflammatory effects of 5-HT receptor antagonist, tropisetron on experimental colitis in rats. Eur J Clin Invest. 2009; 39(5): 375-83. doi: 10.1111/j.13652362.2009.02102.x.

16. Paula VP, Seito LN, Di Stasi LC. Epicatechin used in the treatment of intestinal inflammatory disease: An analysis by experimental models. Evid Based Compl Alter Med. 2012;508902:1-12. Doi: $10.1155 / 2012 / 508902$

17. Manna MJ, Abu-Raghif A, Al-Saraf KM. Therapeutic effect of sildenafil in experimental colitis through anti-oxidative stress and inhibition of adhesion molecules. J Pharm Sci Res. 2017;9(9):16151623.

18. Niu X, H. Zhang H, Li W. Protective effect of cavidine on acetic acidinduced murine colitis via regulating antioxidant, cytokine profile and NF- $\kappa \mathrm{B}$ signal transduction pathways. Chem Biol Interact. 2015;239:34-45. Doi: 10.1016/j.cbi.2015.06.026

19. Mehesen MN, Gouda NA, Khorshid OA. Comparative study of the anti-inflammatory effect of simvastatin, rosuvastatin alone and combined with prednisolone on experimental model of inflammatory bowel disease. Inter J Acad Res. 2015;7(3A):183-191.

20. Amirshahrokhi K, Bohlooli S, Chinifroush MM. The effect of methylsulfonylmethane on the experimental colitis in the rat. Toxicol Appl Pharmacol. 2011;253(3)197-202. Doi: https://doi.org/10.1016/j.taap.2011.03.017

21. Gaudio E, Taddei G, Vetuschi A, Sferra R, Frieri G. Dextran sulfate sodium (DSS) colitis in rats: clinical, structural, and ultrastructural aspects. Dig Dis Sci. 1999;44(7):1458-1475. Doi: https://doi.org/10.1023/A:1026620322859

22. Bertevello PL, Logullo ÂF, Nonogaki S, Campos FM, Chiferi V. Immunohistochemical assessment of mucosal cytokine profile in acetic acid experimental colitis. Clin. 2005;60(4):277-86. Doi: http://dx.doi.org/10.1590/S1807-59322005000400004

23. Hernández-Rodríguez J, Segarra M, Vilardell C. Tissue production of pro-inflammatory cytokines (IL-1beta, TNF alpha and IL-6) correlates with the intensity of the systemic inflammatory response and with corticosteroid requirements in giant-cell arteritis. Rheumatol. 2004;43(3):294-301. Doi: 10.1093/rheumatology/keh058 
24. Daniel WW. Biostatistics A foundation for analysis in the health sciences. 9th ed. New York: Saunders; 2009. 278 p.

25. Sotnikova R, Nosalova V, Navarova J. Efficacy of quercetin derivatives in prevention of ulcerative colitis in rats. Interciptoxicol. 2013; 6:9-12. doi: 10.2478/intox-2013-0002

26. Zeytunlu M, Korkut M, Akguni E, Firar O, Aynacll M. The comparative effects of calcium channel blockers in an experimental colitis model in rats. Turk J Gastroenterol, 2004; 15 (4), 243-249.

27. Banerjee S, Ghosh S, Sinha K, Chowdhury S, Sil PC. Sulphur dioxide ameliorates colitis related pathophysiology and inflammation, J Tox. 2019;412:63-78. Doi: http://doi.org/10.1016/j.tox.2018.11.010

28. Xiao YT, Yan WH, Cao Y, Yan JK, Cai W. Neutralization of IL-6 and TNF- $\alpha$ ameliorates intestinal permeability in DSS-induced colitis, J Cyto. 2016;83:189-192. Doi: doi.org/10.1016/j.cyto.2016.04.012.

29. Gupta RA, MN. Motiwala MN, Mahajan, UN, Sabre SG, Protective effect of Sesbania grandiflora on acetic acid induced ulcerative colitis in mice by inhibition of TNF- $\alpha$ and IL-6. J Ethnopharmacol. 2018;219:222-232. Doi: 10.1016/j.jep.2018.02.043

30. Huang Y, Chen Z. Inflammatory bowel disease related innate immunity and adaptive immunity Am J T Res, 2016; 8(6), 2490-2497.

31. Berin MC, Yang PC, Ciok L, Waserman S, Perdue MH. Role for Il-4 in macromolecular transport across human intestinal epithelium. Am J Physiol.1999;276:1046-52.http://doi.org/10.1152/ajpcell.1999.276.5C1046.

32. Herbert DR, Yang JQ, Hogan SP. Intestinal epithelial cell secretion of RELM- $\beta$ protects against gastrointestinal worm infection. J Exp Med. 2009;206:2947-57. Doi: 10.1084/jem.20091268.

33. Takahashi $\mathrm{K}$, Imaeda $\mathrm{H}$, fujimoto $\mathrm{T}, \mathrm{Ban} \mathrm{H}, \mathrm{Bamba} \mathrm{S}$. Regulation of eotaxin-3/CC chemokine ligand 26 expression by $\mathrm{T}$ helper type 2 cytokines in human colonic myofibroblasts. Clin Exp Immunol. 2013;173:323-31. Doi: 10.1111/cei.12117

34. Kasain MT, Page KM, Fish S, Brennan A, Cook TA. Therapeutic activity of an interleukin-4/interleukin-13 dual antagonist on oxazolone-induced colitis in mice. Immunol. 2014;143(3):416-427. Doi: 10.1111/imm.12319.

35. Abdel-Fattah MM, Messiha BAS, Salana AA. Assessment of the mechanistic role of cinnarizine in modulating experimentally induced bronchial asthma in rats. Pharmacol. 2015;96:167-174. Doi: $10.1159 / 000438705$.
36. Fadel M, Mohammad FK. Effect of diphenhydramine and phenobarbital in the concentration of glutathione and malondialdehyde and glucose in plasma and brain of chicks treated with pentylenetetrazol. IJVS. 2019; 33 (2), 97-104. Doi: 10.33899/ijvs.2019.163173.

37. Mitani T, Yoshioka Y, Furuyashiki T, Yamashita Y, Shirai Y, Ashida H. Enzymatically synthesized glycogen inhibits colitis through decreasing oxidative stress, J Free Rad Bio Med. 2017;106:355-367. Doi: 10.1016/j.freeradbiomed.2017.02.048.

38. Wang Z, Li S, Cao Y. Oxidative stress and carbonyl lesions in ulcerative colitis and associated colorectal cancer. Oxid Med Cellular Longev. 2016;9875298:1-15. Doi: dx.doi.org/10/1155/2016/9875298

39. Esmaily H, Hosseini-Tabatabaei A, Rahimian R, Khorasani R, Baeeri M. On the benefits of silymarin in murine colitis by improving balance of destructive cytokines and reduction of toxic stress in the bowel cells. CEJB. 2009;4:204-13. Doi: 10.2478/s11535-008-0053-2

40. Nussbaum C, Klinke,A, Adam M, Baldus S, Sperandio M. Myeloperoxidase: A leukocyte-derived protagonist of inflammation and cardiovascular diseases, Antioxid Redox Signal, 2013;18;692. doi: $10.1089 /$ ars.2012.4783.

41. Ukwueze CS, Akpan ES, Ezeokonkwo RC, Nwosuh CI, Anene BM. Haematological, oxidative stress and electrolyte alterations in puppies with canine parvoviral enteritis. IJVS. 2020; 34 (1), 65-69.

42. Cagin YF, Parlakpinar H, Vardi N, Polat A, Atayan Y, Erdogan MA, Tanbek K. Effects of dexpanthenol on acetic acid-induced colitis in rats. Exp Ther Med. 2016;12(5):2958-2964. Doi: 10.3892/etm.2016.3728.

43. Macíasa C, Villaescusaa R, del Vallea L, Boffilb V, Corderoa G, Hernándezb A, Hernándeza P, Ballestera JM.. Endothelial adhesive molecules ICAM-1, VCAM-1, and E-Selectin in patients with acute coronary syndrome, Instituto de Cardiología y Cirugía Cardiovascular. 2003; La Habana. Cuba., 56(2), 137-144. doi: 10.1016/s03008932(03)76837-7.

44. Su Y, lei X, liu L. The role of endothelial cell adhesion molecules Pselectin, E-selectin and intercellular adhesion molecule-1 in leucocyte recruitment induced by exogenous methylglyoxal, Immunology. 2012; 137(1), 65-79. doi: 10.1111/j.1365-2567.2012.03608.x

45. Haress NG. Cinnarizine: Comprehensive profile. Profiles Drug Sub Ex Rel Method. 2015;40:1-41. Doi: 10.1016/bs.podrm.2015.01.001. 